\title{
TOLERANCE TO ORAL THYROID AND REACTION TO INTRAVENOUS THYROXINE IN SUBJECTS WITHOUT MYXEDEMA
}

\author{
By A. W. WINKLER, P. H. LAVIETES, C. L. ROBBINS, and E. B. MAN \\ (From the Departments of Internal Medicine and of Psychiatry, Yale University School of \\ Medicine, and from the Medical Service of the New Haven Hospital, New Haven)
}

(Received for publication December 9, 1942)

The failure of certain non-myxedematous subjects to respond to large doses of oral dried thyroid has been previously noted (1). The lack of responsiveness contrasts sharply with the sensitivity to dried thyroid invariably evinced by patients with true myxedema $(1,2)$. In this paper, the responses of various non-myxedematous subjects to thyroid medication are described. In certain of these individuals, the response to intravenous thyroxine was compared with that to oral thyroid substance.

\section{MATERIALS AND METHODS}

The mode of attack paralleled that previously employed in the study of myxedematous patients (1). Over a period of months or years, the basal metabolic rate (hereafter referred to as the "BMR") of each patient was determined at intervals. Oral dried thyroid in various dosages, or courses of intravenous thyroxine, were given from time to time during the period of study. The response of the patient to each procedure could thus be evaluated against the background of his entire course. Difficulties in interpretation arising from shifts in the level of the BMR, from changing responses to the same dose of thyroid and from single aberrant determinations, were in this way minimized. No subjects who did not take the same dose of dried thyroid for at least two months were included. Special care was taken to eliminate all patients thought to be unreliable in taking their medication. All subjects with a clinical picture suggesting the presence of myxedema were excluded. About thirty-six subjects in all were selected, from a much larger group of patients studied, for inclusion in this report; five of the patients were studied in great detail. Six patients received one or more courses of intravenous thyroxine (Squibb), injections being given every three or four days. The dry thyroxine was dissolved in dilute sodium hydroxide a few minutes before injection. The method for the determination of serum iodine was that of Riggs and Man (3).

\section{RESULTS}

(A) Lack of effect on the BMR of long continued administration of dried thyroid

(1) Subjects taking five or more grains of thyroid extract daily without elevation of the BMR

$$
\text { (A44014, A13481, 85533) }
$$

In Figures 1, 2, and 3 are presented graphically the courses of three patients who repeatedly exhibited an ability to tolerate doses of thyroid of

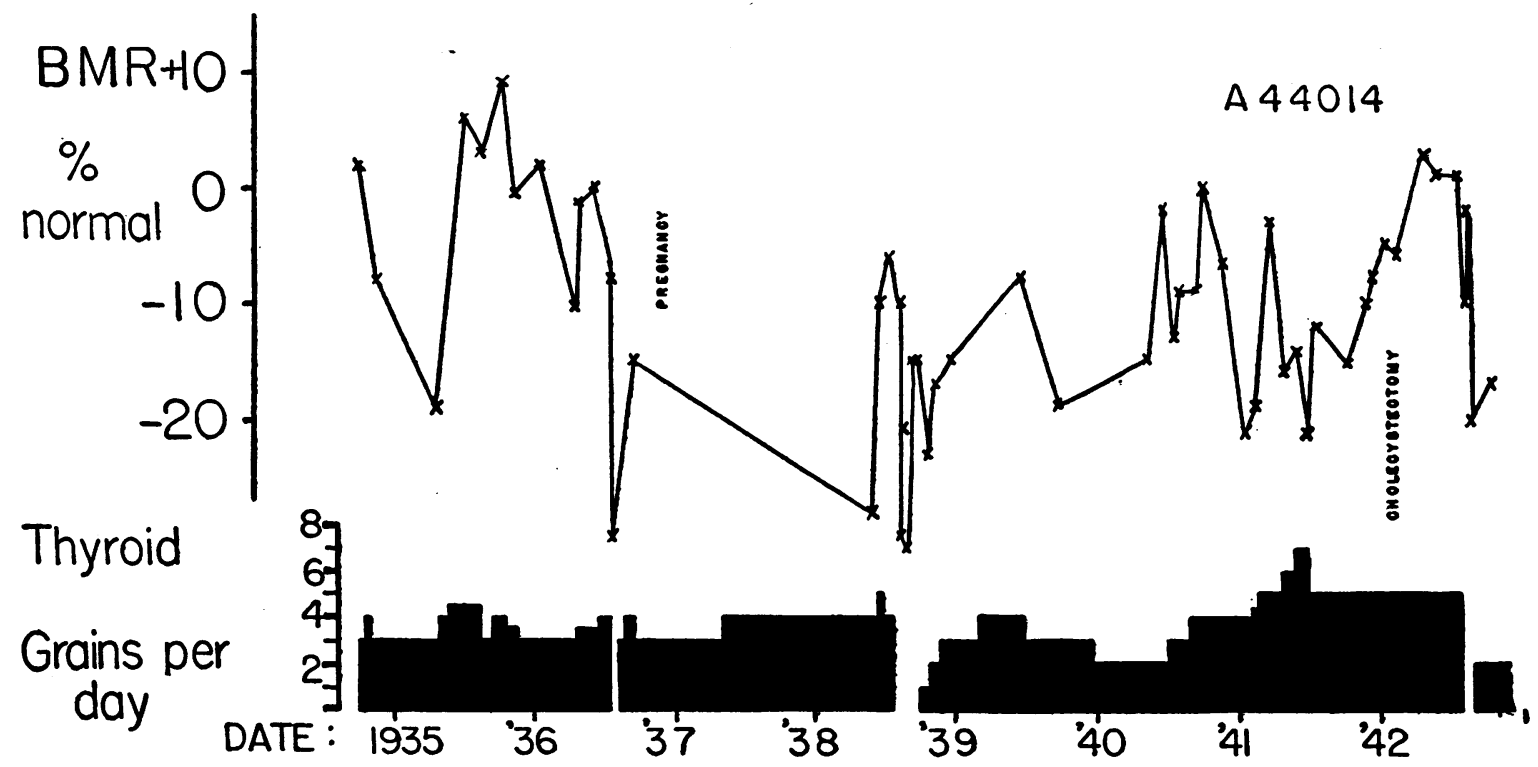

Fig. 1. Non-Myxedematous Subject with Persistently Low Basal Metabolic Rates, Even When Taking Five or More Grains of Thyroid by Mouth DaIly 


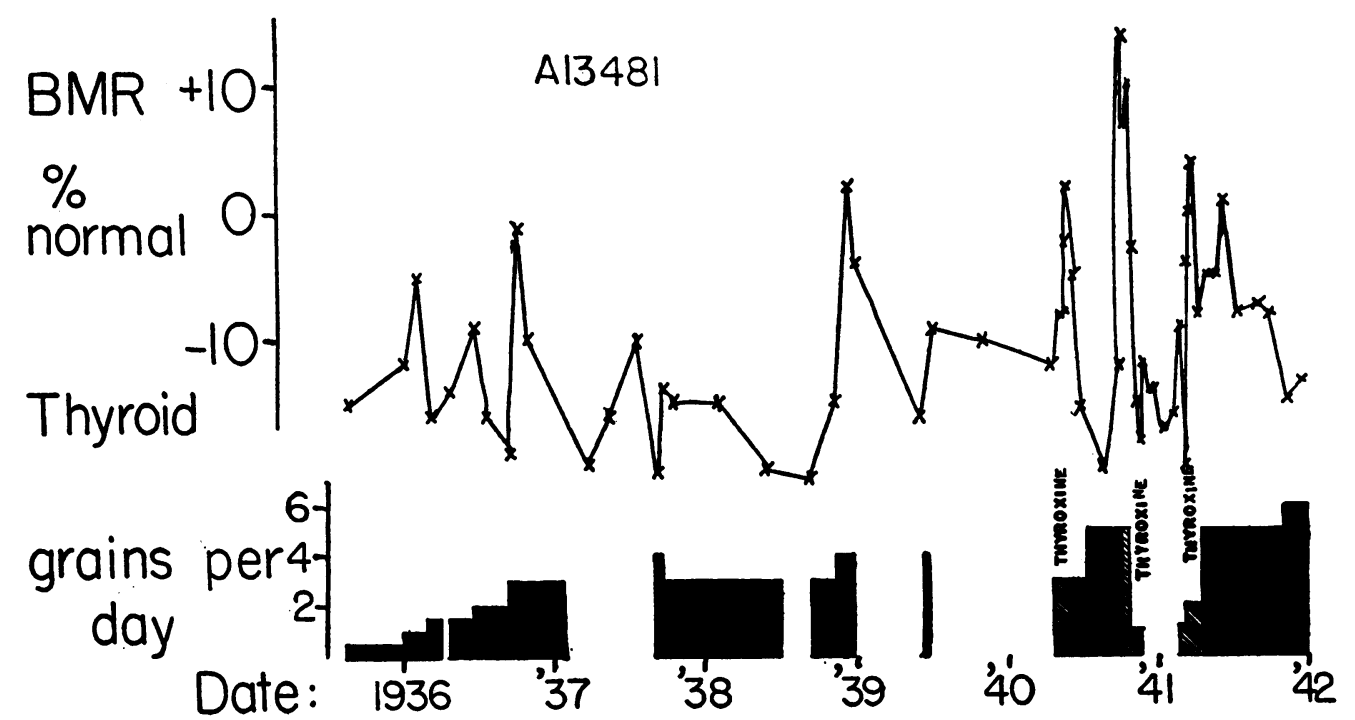

Fig. 2. Non-Myxedematous Subject with Persistently Low Basal Metabolic Rates, Even When Taking Five or More Grains of Thyroid by Mouth Daily

Note response to intravenous thyroxine in iodoequivalent amounts.

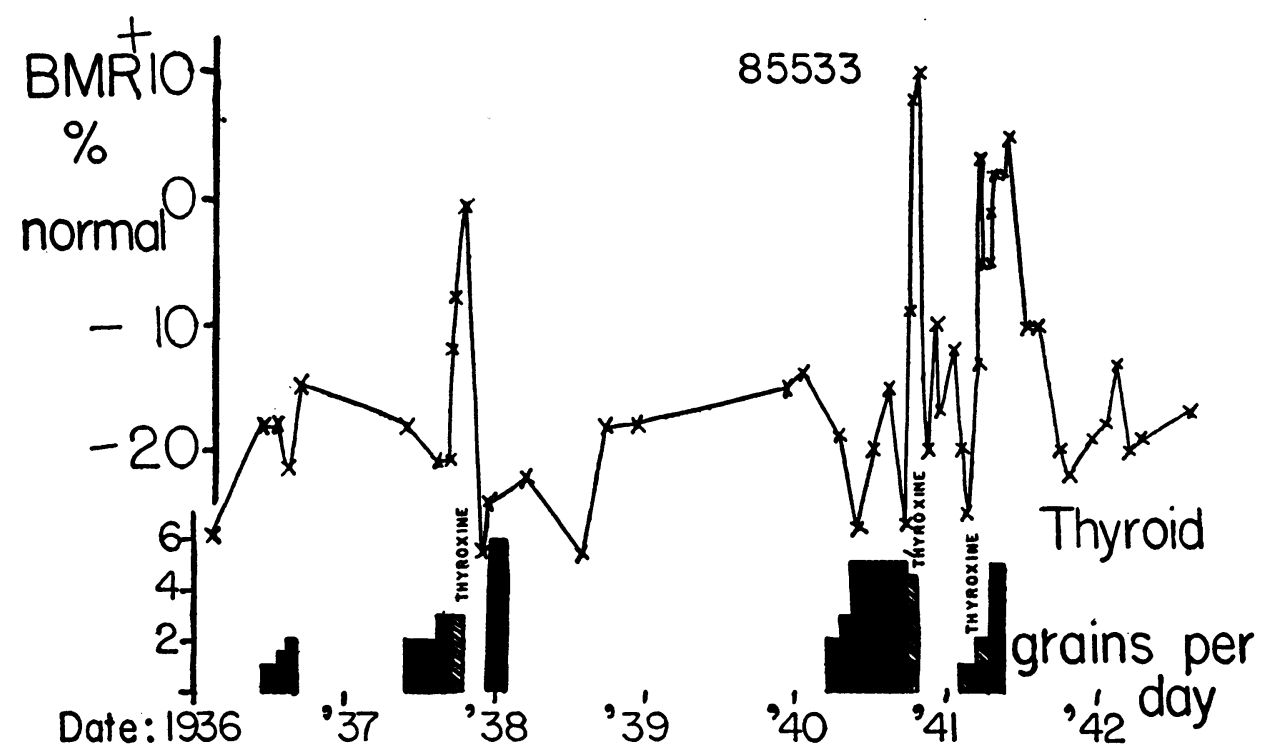

Fig. 3. Non-Myxedematous Subject with Persistently Low Basal Metabolic Rates, Even When Taking Five or More Grains of Thyroid by Mouth Daily

Note response to intravenous thyroxine in iodoequivalent amounts.

five or more grains without any persistent increase of the BMR or of the pulse rate. It cannot be said, however, that the thyroid extract was totally without effect in these subjects. For example, case A44014 (Figure 1) received thyroid medication for eight years, with only three brief interludes, in doses ranging between three and seven grains daily. There seems to have been a gradual trend toward a lower level of metabolism as the years have gone by. Although on one occasion she managed to tolerate seven grains of thyroid daily without subjective disturbance and with a BMR of -21 per cent, at other times the administration of five grains daily sufficed to maintain the BMR at normal levels. Furthermore, the $\mathrm{BMR}$ of this patient always dropped below its 
current level with each interruption of thyroid medication, though it later tended to rise spontaneously again. There was also a very rapid weight gain whenever thyroid medication was interrupted, together with a subjective sensation of weakness. The weight gain and the subjective weakness appeared within two or three days after the thyroid was stopped, so that they could hardly have been due to complete exhaustion of thyroid effect. Serum iodine concentration was also affected by thyroid dosage (see Table IV, below). Patient A13481 (Figure 2) exhibited perhaps the most complete indifference to thyroid medication, since the BMR did not rise with as much as six grains daily, and did not fall even when thyroid medication was stopped. Pulse rate was similarly unaffected. There were, however, two instances, one in 1938 and the other in 1941, when the BMR did increase temporarily when the thyroid dosage was increased. Also, there was a marked weight gain whenever thyroid was stopped, indicating that it was not wholly without metabolic effect. $\mathrm{Pa}$ tient 85533 (Figure 3) was.similarly unaffected by a dose of five grains daily, save for a slight tendency to gain weight whenever dried thyroid was discontinued.

In contrast to this indifference to oral thyroid, cases A13481 and 85533 reacted markedly to intravenous thyroxine (A44014 never had a trial of thyroxine). BMR and pulse rose, weight fell, and nervousness and tachycardia developed. The quantitative aspects of this response to thyroxine will be considered below (see Table III).

(2) Subjects without response of the BMR to a daily dosage of three or four grains, but with response to five or six grains of dried thyroid daily (16186, A29887)

Patient 16186, whose course is presented in Figure 4 , had a BMR of about -20 per cent whenever she received no thyroid. On three grains daily, there was no consistent change; on four grains daily, the BMR was sometimes but not always a little elevated; while on five grains, the BMR regularly rose to the average normal level. This increase was accompanied by a slight rise in the pulse rate, but there was no real tendency toward weight loss. Iodine concentration in serum also responded to changes in thyroid medication (see Table IV).

The response of patient A29887 was quite similar to that of 16186 . The reaction of the BMR during the eight months of administration of three grains daily is especially interesting, in that an initial elevation of the BMR to +20 per cent was succeeded by a fall almost to the initial level, in spite of the continued administration of dried thyroid. A daily dose of four grains was also without much effect, but six grains daily produced an elevation of the BMR to +25 per cent,

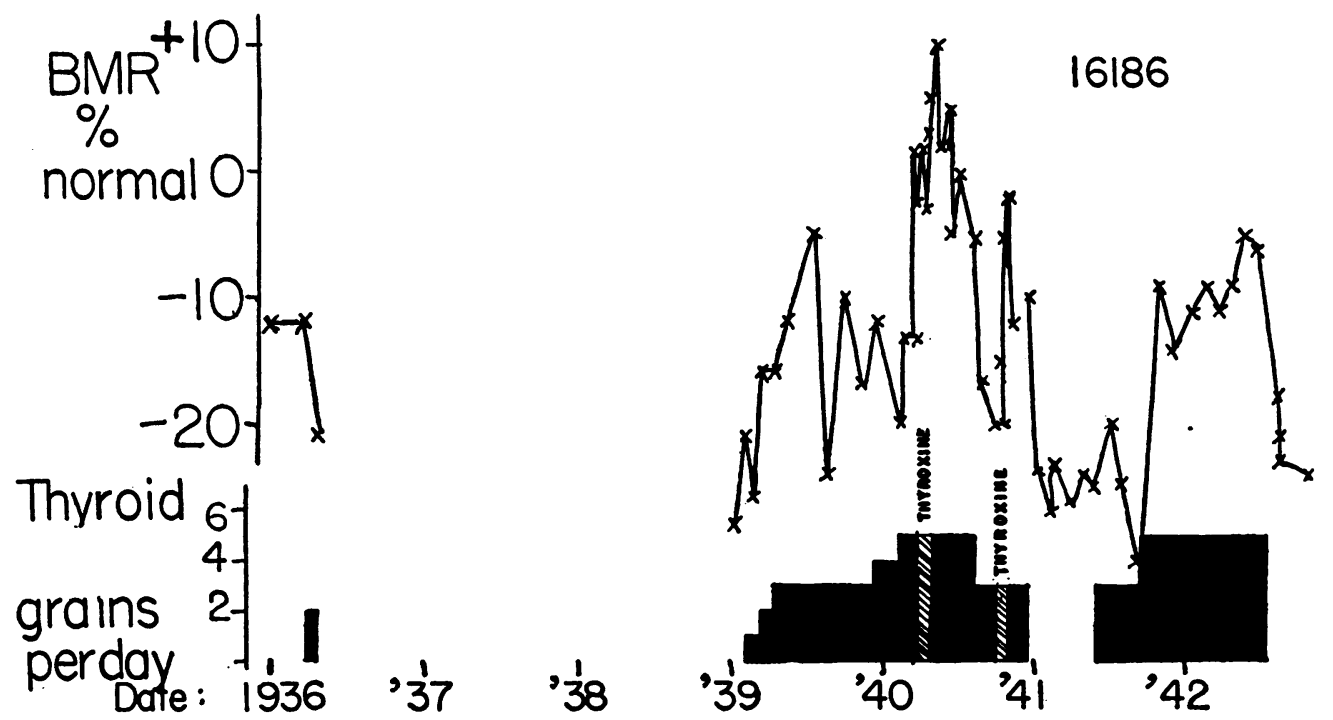

Fig. 4. Rise of the BMR with Five but Not with Three Grains of Dried Thyroid Daily; Positive Response to Intravenous Thyodine in Iodoequivalent Amounts 
TABLE I

Patients, other than those of Figures 1 to 5, failing to exhibit any consistent elevation of the BMR after taking thyroid extract for several months

\begin{tabular}{|c|c|c|c|c|c|c|}
\hline$\underset{\text { ber }}{\text { Num- }}$ & Age & Diagnosis & $\begin{array}{l}\text { Dose of } \\
\text { thyroid, }\end{array}$ & $\begin{array}{c}\text { Dura- } \\
\text { tion }\end{array}$ & $\begin{array}{l}\text { Initial } \\
\text { BMR }\end{array}$ & $\begin{array}{l}\text { Final } \\
\text { BMR }\end{array}$ \\
\hline $\begin{array}{r}1 \\
2 \\
3 \\
4 \\
5 \\
6 \\
7 \\
8 \\
9 \\
10 \\
11 \\
12 \\
13 \\
14 \\
15 \\
16 \\
17 \\
18 \\
19\end{array}$ & $\begin{array}{c}\text { years } \\
60 \\
16 \\
55 \\
48 \\
12 \\
55 \\
39 \\
27 \\
16 \\
35 \\
20 \\
32 \\
28 \\
53 \\
43 \\
37 \\
60 \\
42 \\
35\end{array}$ & $\begin{array}{l}\text { Arteriosclerosis, hypometabolism } \\
\text { Obesity, hypometabolism } \\
\text { Arteriosclerosis, hypometabolism } \\
\text { Neurosis, hypometabolism } \\
\text { Alopecia areata } \\
\text { Arteriosclerosis, hypometabolism } \\
\text { Hypometabolism } \\
\text { Syphilis, hypometabolism } \\
\text { Obesity } \\
\text { Hirsutism, obesity } \\
\text { Infantilism, mild } \\
\text { Obesity, neuralgia } \\
\text { Diabetes, obesity } \\
\text { Simple goiter, hypometabolism } \\
\text { Anemia, hypometabolism } \\
\text { Simple goiter, hypometabolism } \\
\text { Simple goiter, subtotal thyroidectomy, hypertension } \\
\text { Simple goiter, subtotal thyroidectomy } \\
\text { Obesity }\end{array}$ & $\begin{array}{l}\begin{array}{c}\text { grains } \\
\text { per day }\end{array} \\
1,2,3,4 \\
2,3,4 \\
2,5,3,4 \\
1,2 \\
2,3 \\
1,2,3 \\
2,5 \\
1,2 \\
1,2 \\
1,2 \\
1,2 \\
1,1.5 \\
1 \\
1 \\
1 \\
0.5,1 \\
1 \\
1 \\
0.5,1\end{array}$ & $\begin{array}{c}\text { months } \\
5 \\
30 \\
7 \\
6 \\
48 \\
5 \\
5 \\
9 \\
5 \\
4 \\
96 \\
6 \\
5 \\
40 \\
17 \\
18 \\
8 \\
17 \\
8\end{array}$ & 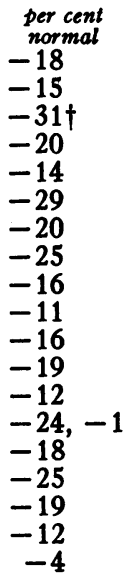 & 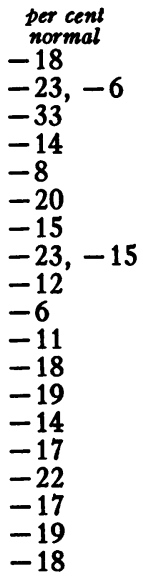 \\
\hline
\end{tabular}

* All but number 19 were females.

$\dagger-6$ per cent two years later.

which was sustained for the two-month period during which this large dosage was continued. There was a concomitant elevation of the pulse rate, weight loss, and slight nervousness. Subjective disturbance was, however, slight. Unlike the other four patients showing adaptation to large doses, this patient had initially a normal BMR.

Both of the patients in this group reacted with an elevation of the BMR, and an increased pulse rate to intravenous thyroxine. Their response to this medication will be considered in detail below (see Table III).

\section{(3) Adaptation to four grains or less of oral thyroid daily}

In Table $I$ are summarized the diagnoses and metabolic data concerning nineteen other subjects failing to exhibit any consistent elevation of the BMR after taking dried thyroid for several months. Necessarily, such a compact summary omits much pertinent detail. In many cases, it was difficult to assign a definite value to the control BMR, since the BMR on no thyroid medication varied considerably from time to time. The BMR values in the table are frequently averages of two or more determinations. Nevertheless, it is obvious that the $B M R$ in these patients failed to exhibit much change, even though oral thyroid extract had been given for weeks or months. In several of these subjects, there was a transitory elevation of the BMR after three or four weeks of thyroid medication, with a subsequent decline to initial levels. Occasionally, the BMR actually decreased.

This was not an unselected group of cases. In most of them, dried thyroid extract was given for its possible therapeutic effect on hypometabolism, on obesity, or on both. Since attempts to raise the dose of thyroid above one grain daily were only successful in those patients who did not react unfavorably, this list automatically excludes many of those who did not tolerate it well. Subjective reaction and metabolic response were not invariably linked. For example, case 19 developed palpitation and perspired intensely whenever the dose of thyroid was increased above one grain daily, yet the BMR on one grain was actually lower than the initial BMR.

All but one of the patients were females. This may be in part a reflection of the economic situation of the group studied, since the women, more readily than the men, could afford to spend regularly a portion of the working day waiting in the office or dispensary and having the repeated BMR determinations required by this study. There was but one patient who did not at one time or another 
TABLE II

Patients showing no tolerance of the BMR to prolonged administration of oral thyroid extract*

\begin{tabular}{|c|c|c|c|c|c|c|}
\hline$\underset{\text { ber }}{\text { Num- }}$ & Age & Diagnosis & $\begin{array}{l}\text { Dose of } \\
\text { thyroid. }\end{array}$ & $\underset{\text { tion }}{\text { Dura- }}$ & $\begin{array}{l}\text { Initial } \\
\text { BMR }\end{array}$ & $\begin{array}{l}\text { Final } \\
\text { BMR }\end{array}$ \\
\hline $\begin{array}{r}1 \\
2 \\
3 \\
4 \\
5 \\
6 \\
7 \\
8 \\
9 \\
10 \\
11 \\
12\end{array}$ & $\begin{array}{c}\text { years } \\
60 \\
\mathbf{5 4} \\
41 \\
35 \\
52 \\
24 \\
35 \\
42 \\
22 \\
50 \\
36 \\
21\end{array}$ & $\begin{array}{l}\text { Arteriosclerosis, hypometabolism } \\
\text { Simple goiter } \\
\text { Hypometabolism } \\
\text { Hypometabolism } \\
\text { Hypometabolism } \\
\text { Obesity, headaches } \\
\text { Obesity, hypometabolism } \\
\text { Obesity, goiter } \\
\text { Sterility, hypometabolism } \\
\text { Obesity, hypometabolism } \\
\text { Hypometabolism } \\
\text { Amyloidosis, tubercular enteritis }\end{array}$ & 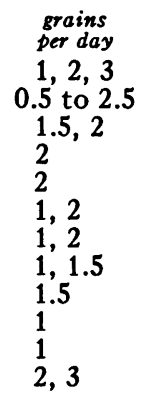 & $\begin{array}{c}\text { months } \\
7 \\
10 \\
6 \\
5 \\
2 \\
9 \\
8 \\
5 \\
4 \\
60 \\
24 \\
12\end{array}$ & $\begin{array}{c}\text { per cent } \\
\text { normal } \\
-24 \\
-10 \\
-18 \\
-12 \\
-23 \\
-15 \\
-22 \\
-6 \\
-22 \\
-25 \\
-34 \\
-22\end{array}$ & $\begin{array}{c}\text { per cent } \\
\text { normal } \\
-9 \\
+9 \\
-3 \\
+7 \\
-8 \\
-1 \\
-12 \\
+15 \\
-12 \\
-10 \\
-20 \\
-5\end{array}$ \\
\hline
\end{tabular}

* All but number 12 were females.

have a BMR below - 10 per cent; as has been mentioned, this was often the initial justification for instituting thyroid medication. Various symptoms led the physician to determine the BMR in the first place. Most commonly these were obesity, coolness, dryness of the skin, alopecia, somnolence, and menorrhagia. Although some of these symptoms are similar to those found in true myxedema, all cases in which, in retrospect, there is any real possibility of the presence of this disease have been excluded. It cannot be asserted that any syndrome consisting of some of these symptoms and a low BMR can be at all sharply defined, yet it was our impression that many of these patients clinically had a good deal in common. Thyroid medication was without much beneficial subjective or objective effect in the majority of these subjects. A few found that thyroid medication made it easier to prevent a gain in weight, and continued to use it for this purpose. Certain individuals did feel more energetic while receiving thyroid; this was not necessarily correlated with any change in the BMR. Usually, the patients took thyroid for a period of a few

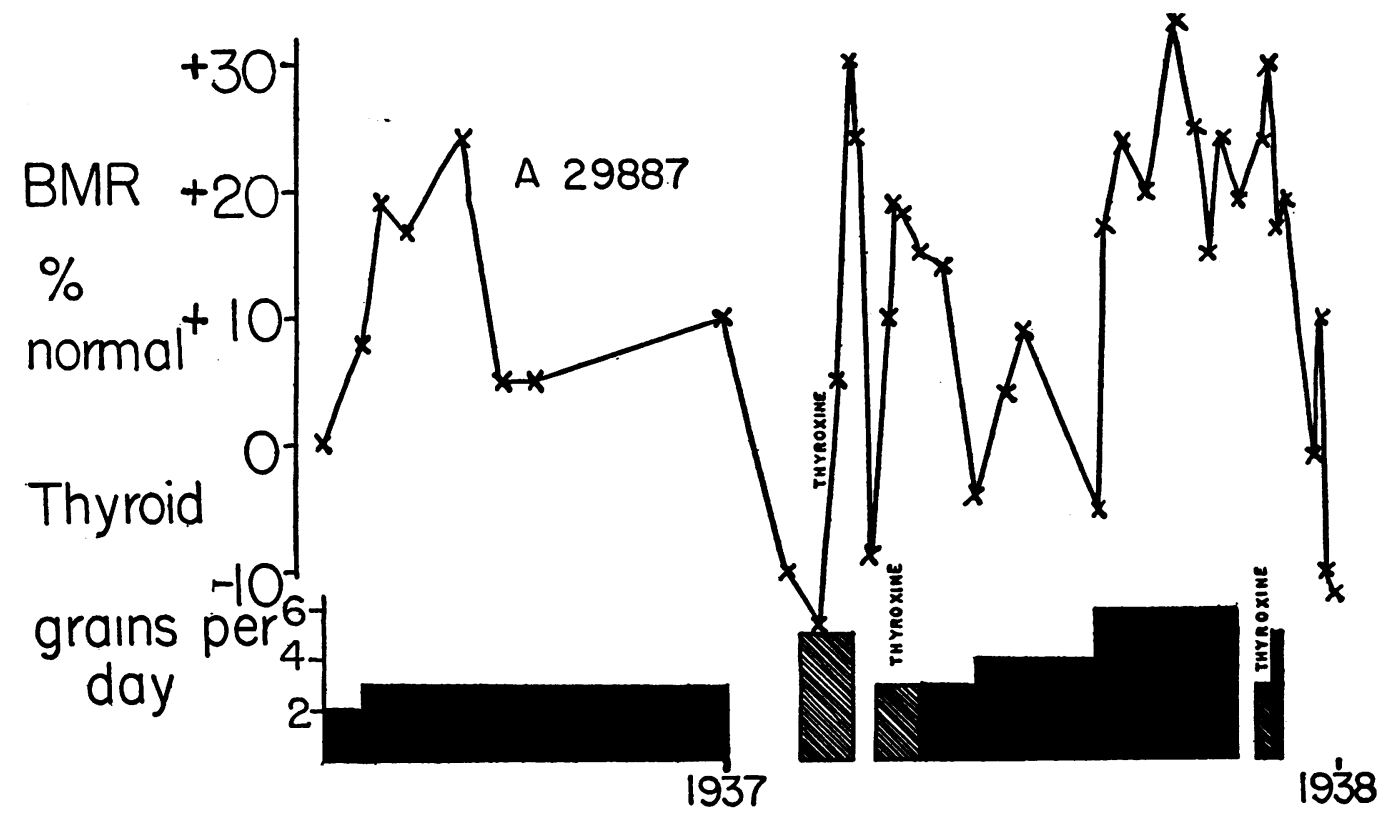

Fig. 5. Rise of the BMR with Six but Not with Four Grains of Dried Thyroid DaIly; Positive Response to Intravenous Thyroxine in Iodoequivalent Amounts 
TABLE III

Quantitative effects of intravenous thyroxine in various dosages

\begin{tabular}{|c|c|c|c|c|c|c|}
\hline $\begin{array}{c}\text { Case } \\
\text { number }\end{array}$ & Dose & $\begin{array}{c}\text { Weeks } \\
\text { thyroxine } \\
\text { was } \\
\text { given }\end{array}$ & $\begin{array}{c}\text { Average } \\
\text { initial } \\
\text { BMR }\end{array}$ & $\begin{array}{l}\text { BMRs while } \\
\text { on thyroxine* }\end{array}$ & $\begin{array}{c}\text { Average } \\
\text { increase } \\
\text { of BMR on } \\
\text { thyroxine } \\
\end{array}$ & Effect of oral thyroid medication \\
\hline A13481 & $\begin{array}{c}\text { mgm. } \\
\text { per day } \\
0.64 \\
1.00 \\
0.29 \\
0.29 \\
0.43\end{array}$ & $\begin{array}{l}5 \\
3 \\
3 \\
3 \\
5\end{array}$ & $\begin{array}{c}\text { per cent } \\
-15\end{array}$ & $\begin{array}{c}\text { per cent } \\
-3,+1,-5 \\
+7,+11 \\
-18,-11 \\
-9,-19 \\
+1,+4,-9,-5\end{array}$ & $\begin{array}{c}\text { per cent } \\
13 \\
24 \\
0 \\
1 \\
7\end{array}$ & No response to 6 grains daily \\
\hline 85533 & $\begin{array}{l}0.67 \\
1.00 \\
0.28 \\
0.43\end{array}$ & $\begin{array}{l}2 \\
3 \\
5 \\
5\end{array}$ & -19 & $\begin{array}{c}-2 \\
+9,+10 \\
-26,-13 \\
-5,-5,-2,+2\end{array}$ & $\begin{array}{r}17 \\
29 \\
0\end{array}$ & No response to 5 grains daily \\
\hline 16186 & $\begin{array}{l}1.00 \\
0.64\end{array}$ & $\begin{array}{l}5 \\
4\end{array}$ & -23 & $\begin{array}{c}+3,+6,+8 \\
-7,-2\end{array}$ & $\begin{array}{l}29 \\
18\end{array}$ & $\begin{array}{l}\text { No response to } 3 \text { but rise on } 5 \text { grains } \\
\text { daily }\end{array}$ \\
\hline A29887 & 0.60 & 3 & -4 & $+19,+17,+16$ & 21 & $\begin{array}{l}\text { Adaptation to } 4 \text { but sustained rise on } 6 \\
\text { grains daily }\end{array}$ \\
\hline Table I, 4 & $\begin{array}{l}0.53 \\
0.80\end{array}$ & $\begin{array}{l}2 \\
3\end{array}$ & -20 & $+4,-2$ & $\begin{array}{r}2 \\
21\end{array}$ & No response to 3 grains daily \\
\hline Table II, 5 & 0.33 & 6 & -22 & $-21,-6,-15$ & 4 & No response to 2 grains daily \\
\hline
\end{tabular}

* After two weeks or more.

months, and then stopped it on their own initiative because it did them little good. On the other hand, no positive deleterious effects were demonstrated. In general, the appearance and reactions of the patients remained unaffected either by the commencement or the cessation of thyroid medication. In this respect, the patients of this group differ sharply from patients with true myxedema, who regularly show both subjective and objective improvement even on small doses of thyroid.

\section{(B) Persistent elevation of the BMR following long continued administration of dried thyroid}

In the course of this study, a considerable number of subjects were encountered who failed to exhibit any adjustment to prolonged administration of dried thyroid. Occasionally, these patients turned out to have mild myxedema, but in many instances, they derived no subjective or objective benefit from thyroid medication, nor did they have any other stigmata of thyroid deficiency. In Table II are summarized the protocols of twelve patients falling into this group. The number of patients is smaller than the number listed in Table I, mainly because the patients of this second group often developed unpleasant subjective reactions, such as palpitation, so promptly that they refused to continue thyroid medication for any prolonged period. Only those willing to continue medication for more than two months are included in Table II. The predominance of females is notable. The types of disorders from which these patients suffered is also very similar to those of the patients in Table I.

\section{(C) Quantitative comparison of the effects of oral thyroid and of intravenous thyroxine in six subjects}

The four subjects presented in Figures 2, 3, 4, and 5 all received courses of intravenous thyroxine and all responded to a sufficient dosage with an increase of the BMR and of the pulse rate. Also, case 4 of Table I and case 5 of Table II received thyroxine. The responses of these six subjects to the different courses of thyroxine, together with a resumé of their responses to oral thyroid, are presented in Table III. In Figure 6, the average increase in the BMR is plotted graphically against the daily dose of thyroxine in each subject. The usual response of subjects with true 
myxedema to thyroxine (2), indicated by the dotted line, is included for comparison.

This figure indicates that in the non-myxedematous subjects, more than $0.3 \mathrm{mgm}$. of thyroxine per day was necessary to raise the BMR, and that $1.0 \mathrm{mgm}$. of thyroxine daily was necessary to increase the BMR by +25 or +30 per cent. This is about the effect produced in the myxedematous subject by 0.2 or $0.3 \mathrm{mgm}$. of thyroxine daily, so that evidently all these non-myxedematous subjects were only about one-third as responsive to thyroxine as were those with myxedema. One milligram of thyroxine contains about the same total amount of iodine as 4.5 or $\mathbf{5 . 0}$ grains of dried thyroid (although only about 0.3 of the iodine in the latter is thyroxine iodine). In total iodoequivalent amounts, therefore, thyroxine was much more effective than oral thyroid in four (A13481, 85533, 16186, A29887), and somewhat more effective in two (Table I, case 4 and Table II, case 5 ), of the subjects tested. ${ }^{1}$ At the same

1 Non-myxedematous subjects do not respond even to the thyroxine content alone of their oral medication as time, it was much less effective than it would have been in a myxedematous subject. This is another point of difference between the reactions of these patients and of those with myxedema, since the latter respond with the same increase of the BMR to oral thyroid and to intravenous thyroxine when given in iodoequivalent amounts.

\section{(D) Effect of oral thyroid medication on the concentration of iodine of serum}

The little information available on the variations of the serum iodine in these patients is presented in Table IV. The serum iodine concentration of case 16186 , while receiving three grains of thyroid daily, was about the same as the concentration

actively as do those with myxedema. About 0.3 of the iodine content of thyroid substance is present as thyroxine iodine. Hence, 6 grains of thyroid, containing about 72 mgm. of total iodine, contains some $22 \mathrm{mgm}$. of thyroxine iodine, and therefore $33 \mathrm{mgm}$. of thyroxine. This is a sufficient daily dose of thyroxine to produce a rise of 20 per cent or more in any cases of myxedema; yet, in at least two of the non-myxedematous subjects, 6 grains of oral thyroid daily were without any effect on the BMR.

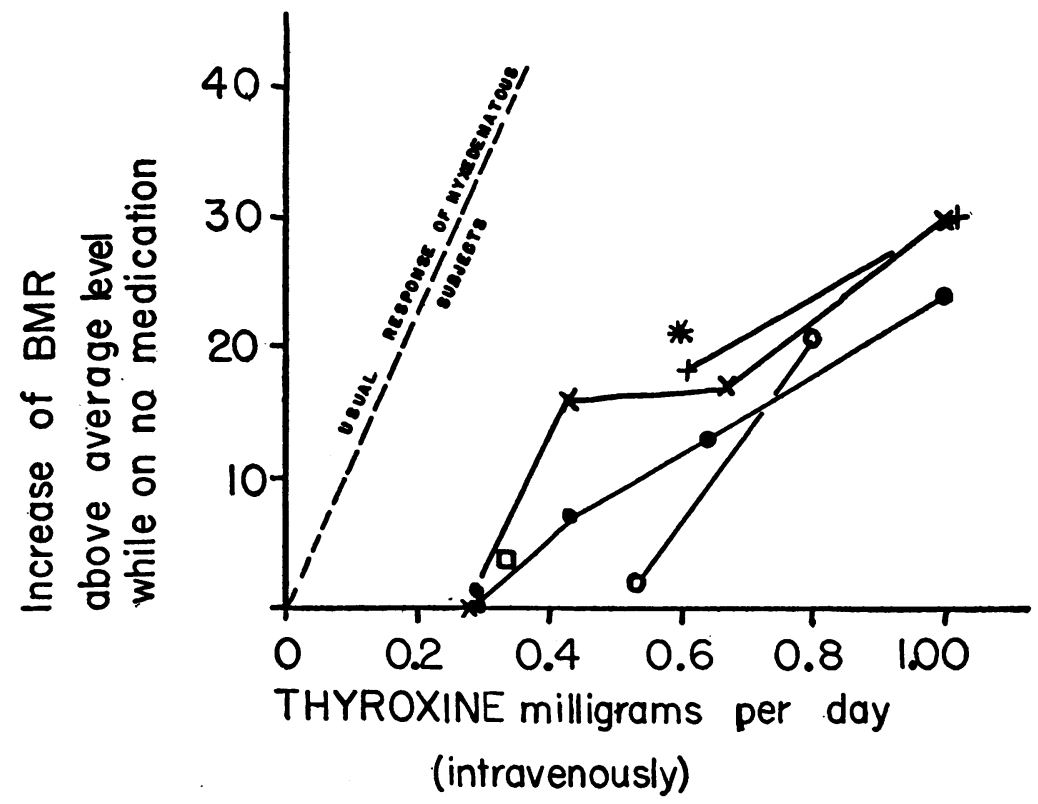

Fig. 6. Response of BMR in Six Non-Myxedematous Subjects to VARIOUS Doses of THYROXINE

Each point corresponds to the average BMR after a course of two weeks or more of intravenous thyroxine in the dose indicated. There is no response unless more than 0.3 milligrams of thyroxine are given daily, and even with larger doses, the response is much less than that usually found in myxedematous subjects. 
TABLE IV

Serum iodine and thyroid dosage

\begin{tabular}{|c|c|c|c|c|c|}
\hline \multirow{2}{*}{$\begin{array}{c}\text { Case } \\
\text { number }\end{array}$} & \multirow{2}{*}{ Date } & \multirow{2}{*}{$\begin{array}{l}\text { Thyroid } \\
\text { medication }\end{array}$} & \multirow{2}{*}{ BMR } & \multicolumn{2}{|c|}{ Serum iodine } \\
\hline & & & & Total & Precipitable \\
\hline & & orains per & per cent & \multicolumn{2}{|c|}{ gamma per cent } \\
\hline 16186 & $\begin{array}{l}\text { December 4,1940 } \\
\text { April 2, 1941 } \\
\text { December 3, } 1941 \\
\text { July 22, 1942 } \\
\text { July 29, 1942 } \\
\text { August 19, } 1942 \\
\text { October 1, 1942 } \\
\text { November 11, } 1942\end{array}$ & $\begin{array}{l}3 \\
0 \\
5 \\
5 ; \text { stopped } \\
0 \\
0 \\
0 \\
0\end{array}$ & $\begin{array}{l}-10 \\
-23 \\
-14 \\
+9 \\
-21 \\
-23 \\
-24 \\
-28\end{array}$ & $\begin{array}{l}4.0^{*} \\
4.8 \\
7.4 \\
5.9 \\
3.4 \\
3.0 \\
4.8 \\
4.8\end{array}$ & $\begin{array}{l}5.8 \\
5.9\end{array}$ \\
\hline$A 13481$ & $\begin{array}{l}\text { December 16, } 1940 \\
\text { Docember 15, } 1941\end{array}$ & $\begin{array}{l}\mathbf{0} \\
\mathbf{6}\end{array}$ & $\begin{array}{r}-15 \\
-8\end{array}$ & $\begin{array}{l}3.0^{*} \\
3.0\end{array}$ & 3.0 \\
\hline A44014 & $\begin{array}{l}\text { December 23, } 1941 \\
\text { July 22, } 1942 \\
\text { July 30, } 1942 \\
\text { August } 6,1942 \\
\text { August } 20,1942 \\
\text { October 2, 1942 } \\
\text { November 4, 1942 } \\
\text { December 2, } 1942\end{array}$ & $\begin{array}{l}5 \\
5 ; \text { stopped } \\
0 \\
0 \\
0 ; \text { start } 2 \\
2 \\
2 \\
4\end{array}$ & $\begin{array}{r}-8 \\
+1 \\
-10 \\
-2 \\
-20 \\
-17 \\
-4 \\
+8\end{array}$ & $\begin{array}{l}6.4 \\
8.1 \\
4.4 \\
3.3 \\
2.8 \\
5.5 \\
5.5 \\
5.0\end{array}$ & $\begin{array}{l}5.9 \\
7.1 \\
3.0\end{array}$ \\
\hline 85533 & December 10, 1940 & $\mathbf{0}$ & -17 & $3.2^{*}$ & \\
\hline
\end{tabular}

* Whole blood iodine divided by 0.6 .

while receiving no thyroid, i.e., four to five gamma per cent. On five grains daily, the concentration was maintained at six or seven gamma per cent. This is correlated with the fact that three grains daily did not affect the BMR, while five grains daily always produced a distinct rise. When thyroid extract was abruptly stopped in July of 1942, serum iodine promptly fell to subnormal levels during the next four weeks, then returned spontaneously to a normal level in ten weeks. Changes in the BMR during this time only partially followed those of the serum iodine. Case A13481 exhibited the same rather low concentration of serum iodine while taking six grains of thyroid daily and while taking no medication; this constancy is correlated with the constancy of the BMR in this patient in spite of changing thyroid dosage. No entirely satisfactory control value of the $B M R$ for the serum iodine is available in case A44014. On five grains of thyroid daily, the serum iodine values, 6.4 and 8.1 gamma per cent, were normal or slightly elevated. Cessation of thyroid medication was followed by a precipitous decline of the serum iodine concentration to subnormal levels, as in case 16186 . Unfortunately, it is not known whether the iodine concentration would have risen again spontaneously, as it did in case 16186 , since the patient resumed thyroid medication. On two grains daily, the serum iodine concentration was 5.5 gamma per cent, a normal value. Case 85533 had only one, rather low, serum iodine determination while on no medication.

\section{DISCUSSION}

There are evidently a good many subjects who can tolerate two or three grains of oral thyroid daily, and some who can tolerate six or seven grains, without effect on the BMR. These patients had no other obvious clinical peculiarity in common, save possibly a tendency toward an initially low BMR. The BMR of myxedematous subjects, on the other hand, regularly increases by twenty-five or thirty per cent on two or three grains of thyroid daily, and shows no tendency to decline even after years of thyroid medication (1). Some physiological explanation of this difference in response is clearly needed. At least three interpretations appear possible: (a) thyroid substance may not be properly absorbed from the gastrointestinal tract of these subjects; $(b)$ the tissues of these people are or become peculiarly insensitive to the usual metabolic stimulation by the thyroid hormone; and $(c)$ the hormone is wholly or in part destroyed, stored, or inactivated, soon after it enters the system.

Although the first possibility, that of deficient absorption, cannot absolutely be eliminated, there are weighty arguments against it. These are: (1) the absence of any other defect in absorption or any gastrointestinal lesion in these patients; (2) the fact that no patient with myxedema, spontaneous or following total thyroidectomy, has been found to have any difficulty in responding to oral thyroid (i.e. no case relieved by small doses of intravenous thyroxine but not by large doses of oral thyroid extract), which makes it improbable that difficulty in absorbing thyroid extract can be at all common; and (3) the fact that this offers no explanation of the quantitatively diminished response of these patients to thyroxine.

There are at least two important objections to the second type of explanation, which assumes the presence or development of a lowered tissue reactivity. In the first place, if this were true, one would expect no difference between the effects of thyroxine intravenously and those of oral thyroid; in iodoequivalent amounts, they should either produce no effect at all or the same, but diminished, 
effect. This is, however, not the case. Thyroxine regularly produced a response while amounts of oral substance containing comparable amounts of iodine produced none. Furthermore, one might expect the serum iodine levels to be abnormally elevated while these insensitive subjects were receiving large amounts of thyroid by mouth; such is, however, not the case.

The third line of explanation-that the hormone is inactivated ${ }^{2}$ after absorption of injectionavoids the difficulties inherent in the first two explanations, and is at least compatible with the facts as they are now known. Under this hypothesis it must be assumed that both oral thyroid and intravenously injected thyroxine tend to be inactivated, but that there is an upper limit to the rate at which this can be done and the amount that can be handled. Therefore, oral thyroid, entering the system gradually, would be more readily inactivated than thyroxine, which is suddenly introduced directly into the circulation. This would explain the fact that thyroxine is more effective than oral thyroid in these subjects, and yet is less effective than in myxedematous subjects. It also could explain the fact that the ability to handle thyroid substance is usually not unlimited, and that it may vary a good deal from one individual to another. It is consistent with the relatively low iodine content of the serum in these subjects while they are receiving large doses of thyroid. Speculation that the agent for this inactivation is the thyroid gland itself is naturally suggested by the extraordinary avidity of the gland for iodine (4). If this were the case we should have an explanation for the fact that the development of tolerance is peculiarly absent in subjects with myxedema, since they, presumably, have no functional thyroid tissue. In these non-myxedematous subjects, the drop of the $\mathrm{BMR}$ on discontinuing thyroid medication is often much more rapid than that seen in myxedema; this also suggests continuing removal of the effective hormone in subjects possessing a thyroid gland. It is not sufficient to assume that the normal thyroid gland

2 The terms "inactivate" and "inactivation" are used to avoid any unwarranted assumption concerning the particular process involved in the inhibition of the usual role of the hormone. Since the process can continue for months and years, it seems unlikely that storage alone, in the thyroid gland or elsewhere, can afford a complete explanation of the phenomenon. merely suppresses its own output of hormone when thyroid is given by mouth, as Farquharson and Squires (5) have suggested. Some subjects manage to tolerate at least twice the normal requirements of thyroid hormone, gauged by the amount necessary to maintain the thyroidless subject. There is, however, evidence from the serum iodine figures (Table IV) that some depression of function may take place, which does not immediately disappear when artificial thyroid administration is discontinued.

This hypothesis necessarily requires much more experimental work for its confirmation. A study of the serum iodine levels at intervals after thyroxine injection should prove helpful. Many things at present are difficult to interpret, such as the apparent ability of thyroid medication to keep the weight down, even when the BMR is unaffected. For the present, it is advanced as a tentative hypothesis, more consistent with the facts as they are now known than are the alternative hypotheses, and awaiting further experimental investigation to confirm or disprove it.

\section{CONCLUSIONS}

(1) Certain non-myxedematous subjects can tolerate as much as six grains of dried thyroid daily for long periods, without effect on the BMR or on the pulse rate. Many others can tolerate as much as three or four grains daily without effect on the BMR.

(2) These subjects respond to thyroxine intravenously, but require much larger doses than do myxedematous subjects to produce a comparable rise in the BMR.

(3) This behavior is very different from the absence of tolerance and the acute sensitivity to thyroid and to thyroxine of the patient with myxedema.

(4) It is suggested as a working hypothesis that this difference of behavior can best be explained by assuming that the non-myxedematous subject possesses the ability, wanting in the patient with myxedema, to inactivate thyroid substance and intravenous thyroxine.

\section{PROTOCOLS OF CASES}

A44014. This white female of English extraction, born in 1899 , had a subtotal thyroidectomy for simple goiter in 1924. At various times during the next few years, she 
was given two or three grains of thyroid extract daily because of a tendency toward obesity. Cessation of thyroid administration for months at a time had no effect other than a tendency to gain weight. There were no symptoms suggesting myxedema. She was first seen in this clinic in 1934, at which time her BMR, while taking no dried thyroid, was plus 2 per cent. From 1934 to 1942 , she has been treated in this clinic with oral thyroid in doses ranging from three to seven grains daily (Figure 1). For three brief intervals, thyroid was omitted without the development of symptoms suggesting myxedema. In 1936 to 1937, there was an uneventful normal pregnancy, and in 1940, a skin complaint of unknown nature, characterized by subcutaneous tenderness of the arms. This later disappeared spontaneously. In 1941, there was an attack of acute cholecystitis and in 1942, a gall-bladder containing stones was removed surgically without complications. At present (November, 1942), she feels entirely well, and takes small amounts of thyroid in order to counteract her tendency toward obesity.

A13481. This woman, born in Italy in 1899, developed typical Graves' disease in 1932. A subtotal thyroidectomy in two stages was performed in June, 1932, following preliminary treatment with iodine. Pathological examination revealed adenomatous hyperplasia of the thyroid gland. Recovery was complete, the BMR one year after operation being minus 3 per cent. In 1933 to 1934, she went through a normal pregnancy. When seen after an absence of one year, in September of 1935, the BMR was found to be minus 15 per cent. There were no subjective or objective disturbances except for obesity and occasional spells of slight vertigo. During the next six years, she was treated at intervals with oral thyroid and with occasional courses of intravenous thyroxine (Figure 2). Her only complaint during this time was moderate obesity. Cessation or resumption of thyroid were without subjective effect in any dose attempted. Pulse rate was also unaffected. She always tended to gain weight rather rapidly whenever thyroid was omitted.

85533. This female patient, born in Russia in 1885, was found to have pulmonary tuberculosis, involving the right upper lobe, in 1929. This has remained fairly quiescent ever since, although there have been occasional episodes of blood streaked sputum, without fever, weight loss, or roentgenological evidence of progression; at present (1942), there is probably some bronchiectasis as well as old tuberculous fibrosis. In 1936, the BMR was found to be minus 27 per cent. The metabolism test had been suggested because of headaches and some dryness of the hair. There were no stigmata of myxedema and the serum cholesterol concentration was normal. She has been treated off and on since that time with courses of thyroid and of thyroxine (Figure 3). Thyroid seemed entirely without effect on the BMR or on the pulse rate, and produced no subjective benefit. It was therefore finally abandoned in 1941, and the patient has since noticed no change of any sort. Thyroxine produced marked tachycardia, rise in the BMR, weight loss, and nervousness.

16186. This woman, born in Austria in 1887, developed a migratory arthritis in 1931. This was apparently an acute rheumatism superimposed upon an old chronic hypertrophic arthritis. The acute phase disappeared completely within a few months, but the back and the knee joints have been a little stiff ever since. In 1934, there was a sudden detachment of the right retina, which was believed to be due to myopia. No vascular disease could be detected. In 1936, a BMR, taken because of some nervousness and weight loss, was found to be minus 12 per cent on two occasions. Thyroid, two grains daily, was given for a brief period without subjective improvement, and was therefore discontinued. In 1939, the BMR was again found to be minus 29 and minus 22 per cent on two occasions. There were no stigmata of myxedema; thyroid medication was again given in the hope of improving her general lassitude. This has been continued at intervals until the present (Figure 4); she thinks that she feels a little more energetic while taking thyroid, but does not mind doing without it.

A29887. This young girl, born in 1919, has been followed from 1933 until 1942 because of failure to attain a normal stature and because of failure of the menses to appear. General physical status has always been excellent. BMR while taking no thyroid was minus 2 per cent. There were no stigmata of thyroid deficiency. Estrogenic and androgenic activities of the urine were normal. The height $(139 \mathrm{cms}$.) and the menses have been unaffected by courses of antuitrin-S, of thyroid by mouth, and of thyroxine (Figure 5).

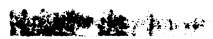

\section{BIBLIOGRAPHY}

1. Winkler, A. W., Criscuolo, J., and Lavietes, P. H.: Quantitative relationship between basal metabolic rate and thyroid dosage in patients with true myxedema. J. Clin. Invest., 1943, 22, 531.

2. Means, J. H.: The Thyroid and Its Diseases. J. B. Lippincott Co., Philadelphia, 1937.

3. Riggs, D. S., and Man, E. B., A permanganate acid ashing micromethod for iodine determinations. I. Values in blood of normal subjects. J. Biol. Chem., 1940, 134, 193.

4. Salter, W. T.: The Endocrine Function of Iodine. Harvard University Press, Cambridge, 1940.

5. Farquharson, R. F., and Squires, A. H.: Inhibition of the secretion of the thyroid gland by continued ingestion of thyroid substance. Tr. A. Am. Physicians, 1941, 56, 87. 